\title{
Lipid Profile and Haematological Indices of Wistar Albino Rats fed Riped, Unripe and Artificially Riped Mangifera indica (Mango) Pulp Formulated Diets
}

\author{
Pauline N. Iheagwam, MSc \\ Eugene N. Onyeike, PhD \\ Benjamin A. Amadi, PhD
}

Department of Biochemistry, Faculty of Science, University of Port Harcourt, Choba, Nigeria

Doi: 10.19044/esj.2019.v15n15p30 URL:http://dx.doi.org/10.19044/esj.2019.v15n15p30

\begin{abstract}
Lipid profile and haematological indices of Wistar albino rats fed naturally riped, unripe and artificially riped mango pulp formulated diets were investigated. Artificially riped mangoes were obtained by wrapping with dark polyethylene bag and others by treatment with calcium carbide and hot water. After inducing ripening, the mango samples were air-dried, ground and used to formulate the $10 \%, 20 \%, 30 \%$ diets fed to rats for 28 days. Results obtained indicated that at $10 \%$ level of incorporation, there was no significant difference in high density lipoprotein concentration in all the groups which ranged from $69.5 \pm 3.29 \mathrm{mg} / \mathrm{dl}$ in calcium carbide group to $72.4 \pm 0.87 \mathrm{mg} / \mathrm{dl}$ in the control group. At 20\% and 30\% levels of incorporation no significant difference in high density lipoprotein was obtained between the controls, unripe the polybag and hot water riped groups but each was significantly higher than values obtained for calcium carbide group. At 10\% level of incorporation low density lipoprotein was highest in polybag group $(88.60 \pm 5.95 \mathrm{mg} / \mathrm{dl})$ followed by calcium carbide group $(88.67 \pm 5.95 \mathrm{mg} / \mathrm{dl})$ but was lowest in the control group $(78.37 \pm 3.75 \mathrm{mg} / \mathrm{dl})$, whereas at $20 \%$ and $30 \%$ levels of incorporation, no consistent pattern was observed. At 10, 20 and $30 \%$ levels of incorporation of samples into the formulated diets, White blood cell count increased while Red blood cell count and haemoglobin concentration decreased in the artificially riped groups compared to the control. Generally, the values of lipid parameters and haematological indices suggest that artificial ripening especially by the use of carbide may not be a good candidate in the ripening of mango fruits.
\end{abstract}


Keywords: Artificial ripening, mango fruits, diet, haematological indices, lipid profile

\section{Introduction}

Fruit; the seed bearing structure formed from the ovary of a flowering plant after flowering is the means of seed dispersal (Mauseth, 2003). Fruits play a vital role in human nutrition and are critical for human existence and sustenance. They supply important supplements in human diet by providing the much needed growth supporting nutrients such as vitamins, minerals, complex starches, proteins, lipids and important phytochemicals required for supporting optimal health (Hayes, 2005, Rossato et al., 2009). Example of fruits include; mango, apple, cashew, orange, grape, water melon, lemon and pineapple. Among the fruits, mango (Mangifera indica)in the Anacardiaceae family generally found in tropical and subtropical regions is known as the king of fruits (Onyeani et al., 2012) due to its nutritious, invigorating and refreshing taste (Farina et al., 2013a).

Adequate consumption of fruits can also improve vision and might assist in preventing numerous age related ailments like osteoarthritis, osteoporosis and dementia (Jacka et al., 2011). Akbaraly et al., (2013) has reported that insufficient intake of fruits such as mango maybe considered as a factor in the higher rates of a number of diseases such as cardiovascular diseases, onset of many cancer such as Prostrate and colon cancer (Boffetta et al., 2010) depression among adolescents, adults, and the elderly, poor vision (Oyebode et al.,2014), and poor mental health among others (Allgo et al., 2001; Adams and Colner,2008).

Fruit consumption is not as high as it should be due to unavailability during off seasons attributed to their rapid ripening, softening and subsequent spoilage and susceptibility to diseases which consequently, limit their storage, handling and transportation (Amarakoon et al., 1999). In order to stall this problem, many climacteric fruits such as mango are therefore harvested prior to ripening and ripening is induced artificially so as to minimize loss. (Goldman et al.,1999). Post-harvest storage of mango fruits is a major challenge in technologically underdeveloped countries such as Nigeria (Gbakon et al., 2018).Fruit ripening is a natural process that initiates a series of biochemical changes responsible for colour and pigment formation, starch breakdown, textural changes, aroma formation and finally fruit abscission (Harbone, 1993), but in order to meet the high demand for seasonal fruit, maximize profit and to minimize post-harvest losses, traders harvest even immature green fruits and subject them to various ripening methods (Igbinaduwa and Aikpitanyi-Iduitua, 2016). Kjuus et al., (2007) reported the use of many artificial methods to induce ripening which includes the utilization of chemical ripening substances such as calcium carbide, ethereal, 
acetylene, pit smoking, dipping into hot water wrapping in dark cellophane bags amongst others (Iroka et al., 2016). These artificially induced fruit ripening methods are said to elicit deleterious effects to the health and wellbeing of man (Kader, 2007; Dhembare and Gholap, 2011a).Information from emerging data suggests that the use of artificial ripening agents in fruit ripening causes abdominal pain, diarrhea, vomiting, headache, dizziness and insomnia which may progress to memory loss and cerebral edema (Dhembare, 2013). The upsurge of demand for food safety has motivated researchers into investigating possible risk common with the use of artificial methods in fruit ripening (Ruchitha, 2008). Owing to the importance of fruits to the health of man, this study was carried out to assess possible changes in lipid profile and haematological indices of rats fed mango fruit formulated diets, occasioned by these artificial ripening methods.

\section{Materials and Methods}

Collection and preparation of samples

Ripe and unripe mango fruits (plate 1) were sourced locally from Okwuato Community in Aboh Mbaise Local Government Area of Imo State, Nigeria. The riped fruits and some of the unripe fruits were cleaned, sliced, air dried, ground and stored in cellophane bagswhile the rest of the unripe fruits were cleaned and given the following treatment; a set was left in the sun for four hours after which the fruits were tied in a clean empty dark poly bag for three days to induce ripening. A second set was put in a plastic bucket containing ground calcium carbide ( $2 \mathrm{~g}$ of calcium carbide/ $100 \mathrm{~g}$ of mango) for 24 hours to induce ripening while the third set was soaked in hot water $\left(100^{\circ} \mathrm{C}\right)$ for $5 \mathrm{mins}$; cleaned and covered with a thin cloth. After ripening was induced in all set, the fruits were sliced, air dried, ground and stored in separate cellophane bags prior to analysis (Iroka et al.,2016). 


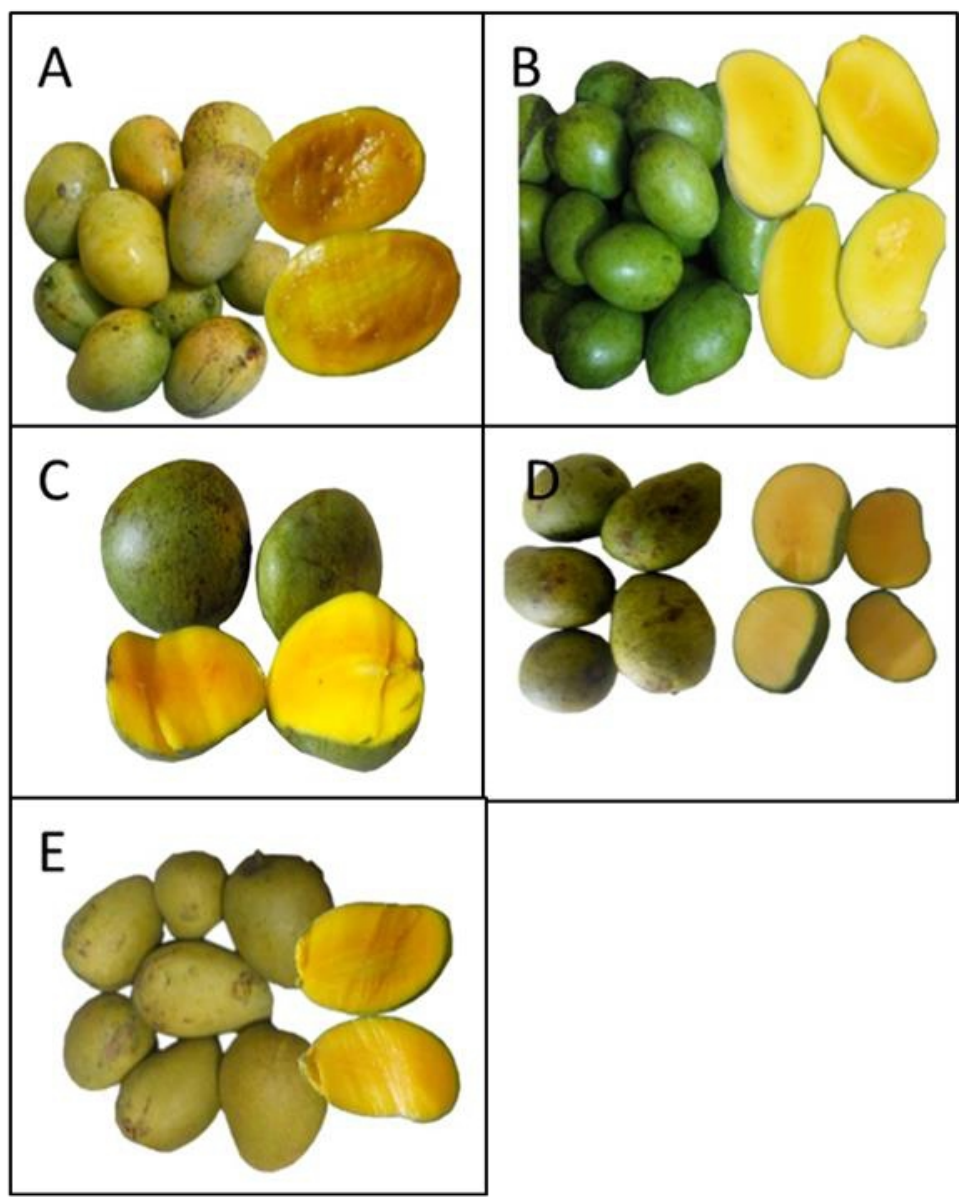

Fig.1 (A)Naturally riped mango fruits. (B) Unripe mango fruits (C) Polybag riped mango fruits (D) Calcium carbide riped mango fruits (E) Hot water riped mango fruits

\section{$\underline{\text { Rat feeding studies }}$}

Ninety Wistar albino rats weighing between $100 \mathrm{~g}$ and $120 \mathrm{~g}$ were obtained from the Animal House of the Department of Anatomy, University of Lagos and were kept in clean plastic cages under a $12 \mathrm{hr}$ light and dark cycle and housed in the Animal House of the Department of Pharmacology, University of Lagos. The rats were acclimatized to the laboratory environment for a period of one week. After acclimatization and randomly assigned into five groups of 18 rats per group. Group one (control) were fed $10 \%, 20 \%$ and $30 \%$ naturally riped mango fruit supplemented diet, while groups two, three, four and five were fed $10 \%, 20 \%$ and $30 \%$ unripe, polybag, calcium carbide and hotwater induced ripened mango formulated diets respectively. Eighteen rats were assigned to each group and were fed adlibitum for 28days. The rats were fed daily for four weeks and left over feed and water were discarded daily. All experimental animals were handled in 
accordance with the US National Institute of Health Guidelines for the Care and Use of Laboratory Animals (2011).

At the end of the feeding studies, $5 \mathrm{ml}$ of blood was collected from nine rats per group (3 rats per sub group for the 10\%. $20 \%$ and $30 \%$ diet groups) by ocular puncture through the optical vein. Four milliliters of the blood collected was transferred into lithium heparin bottles. The blood samples were spun with a Bucket Centrifuge at 4,000 rpm for 5 minutes to ensure proper separation of the plasma from the packed cells. The plasma obtained was kept in plain vial for biochemical analysis while the remaining $1.0 \mathrm{ml}$ was transferred into vials containing anticoagulant ethylenediaminetetraacetic Acid (EDTA) for haematological analysis using ERMA Hematology autoanalyser to obtain values of heamatological indices. All investigations were carried out in the Chemical Pathology laboratory, University of Lagos Teaching Hospital, Idiaraba, Lagos.

\section{Statistical analysis:}

The data were analyzed by the analysis of variance (ANOVA). The difference between the various extracts and animal groups were compared using the Duncan multiple range test. The results are expressed as mean \pm standard deviation. Significance was accepted at $\mathrm{p} \leq 0.05$.

\section{Results}

Results revealed that the high density lipoprotein (HDL) concentration of the rats that were fed $10 \%$ formulated diets, showed no significant $(\mathrm{P}<0.05)$ difference between the control (naturally ripe) and the rest of the group while at the $20 \%$ and $30 \%$ levels only the calcium carbide $(67.77 \pm 0.1 \mathrm{mg} / \mathrm{dl})(65.77 \pm 0.12 \mathrm{mg} / \mathrm{dl})$ group showed significantly $(\mathrm{P}<0.05)$ lower concentrations compared to the control $(72.30 \pm 13.74 \mathrm{mg} / \mathrm{dl})$ $(70.47 \pm 0.81 \mathrm{mg} / \mathrm{dl})$ respectively and the rest of the group (Table1).At $10 \%$ level of incorporation, the values obtained for low density lipoprotein was significantly $(\mathrm{P}<0.05)$ higher in the artificially riped groups compared to the control group while at $20 \%$, values ranged from $(100.57 \pm 0.92 \mathrm{mg} / \mathrm{dl})$ in hot water followed by $(91.07 \pm 13.74 \mathrm{mg} / \mathrm{dl})$ in calcium carbide but was lowest $(82.43 \pm 4.56 \mathrm{mg} / \mathrm{dl})$ in the unripe group whereas at the $30 \%$ level, no significant difference was observed. The concentration of cholesterol at the $10 \%$ and $30 \%$ levels of incorporation of formulated diets, were significantly higher in the artificially riped groups compared to the control while at the $20 \%$ level, the hot water was significantly $(\mathrm{P}<0.05)$ higher compared to the control, unripe and the polybag groups. The values obtained for the triglycerides at $10 \%$ level showed that the control and the unripe groups were significantly lower than the artificially riped groups but at the $20 \%$ and $30 \%$ levels no significant $(\mathrm{P}<0.05)$ variation was observed in all groups. 
The results of the heamatological investigations showed that at $10 \%$ level of incorporation of formulated diets, values obtained for the white blood cell ranged from $16.37 \pm 0.06 \times 10^{10}$ cell/L in the calcium carbide group, followed by $16.27 \pm 0.8 \times 10^{10}$ cell/L in the unripe but was lowest $7.53 \pm 0.06 \times 10^{10}$ cell/ $/ \mathrm{L}$ in the control while at $20 \%$ and $30 \%$ levels hot water group was significantly $(\mathrm{P}<0.05)$ higher than the control, the unripe and the most of the other artificially riped groups.

The Lymphocyte count showed no significant variation at 10 and $30 \%$ levels but at $20 \%$ level, calcium carbide $(59.73 \pm 6.35 \%)$ group was significantly $(\mathrm{P}<0.05)$ higher than the control and the other groups (Table 3$)$.

The values obtained for the percentage neutrophil at $10 \%$ level, ranged from $55.07 \pm 4.62 \%$ in the calcium carbide group to $52.17 \pm 0.23 \%$ in the control but no statistical $(\mathrm{P}<0.05)$ difference was observed at the 20 and $30 \%$ levels.

The Red blood cell count showed that values ranged from $16.37 \pm 0.06 \times 10^{10}$ cell/ $/ \mathrm{L}$ in the calcium carbide group to $7.14 \pm 0.40 \times 10^{10} \mathrm{cell} / \mathrm{L}$ in the control group at $10 \%$, While at the $20 \%$ level the control group was statistically $(\mathrm{P}<0.05)$ higher than only polybag and calcium carbide but did not differ from any of the groups at the $30 \%$ level.

Also heamoglobin count at all levels followed a similar pattern and showed that values were highest in the control but lowest in the calcium carbide group (Tables 2-4).

Results obtained for the packed cell volume at the three levels of formulated diet showed no statistically significant $(\mathrm{P}<0.05)$ difference compared to the control and between the ripening groups.

Platelet count revealed that values followed the same trend at the 10 and $30 \%$ levels. Values ranged from $874.33 \pm 8.08 \%$ and $909.67 \pm 45.61 \%$ in the control groups to $619.33 \pm 21.94 \%$ and $701.00 \pm 55.43 \%$ in the unripe groups respectively but at the $20 \%$ level, the control was significantly (P 0.05 ) higher than the polybag group followed by the unripe group while calcium carbide group was the lowest (Table 3). However, for the mean platelet volume no significant $(\mathrm{P}<0.05)$ difference was observed at all levels of formulated diet (Table2-4). 
Table 1: Lipid profile of Wistar albino rats fed riped, unriped and artificially riped mango pulp (Mangifera indica) formulated diets

\begin{tabular}{|c|c|c|c|c|c|c|c|c|c|c|c|c|}
\hline \multirow{2}{*}{$\begin{array}{l}\text { Paramet } \\
\text {-ers } \rightarrow \\
\text { Group } \downarrow\end{array}$} & \multicolumn{3}{|c|}{$\begin{array}{l}\text { High density lipoprotein } \\
\text { (mg/dl) }\end{array}$} & \multicolumn{3}{|c|}{$\begin{array}{l}\text { Low density lipoprotein } \\
\text { (mg/dl) }\end{array}$} & \multicolumn{2}{|c|}{$\begin{array}{l}\text { Cholesterol } \\
\text { (mg/dl) }\end{array}$} & \multicolumn{3}{|c|}{$\begin{array}{l}\text { Triglycerides } \\
\text { (mg/dl) }\end{array}$} & \multirow[b]{2}{*}{$30 \%$} \\
\hline & $10 \%$ & $20 \%$ & $30 \%$ & $10 \%$ & $20 \%$ & $30 \%$ & $10 \%$ & $20 \%$ & $30 \%$ & $10 \%$ & $20 \%$ & \\
\hline Control & $72.40 \pm 0.87^{1}$ & $72.30 \pm 13.74^{\mathrm{a}}$ & $70.47 \pm 0.81^{1}$ & $78.37 \pm 3.75^{b}$ & $90.67 \pm 3.00^{a, b}$ & $98.00 \pm 0.35^{\prime \prime}$ & $186.17 \pm 3.41$ & $191.10 \pm 3.46^{b}$ & $199.10 \pm 0.00^{\circ}$ & $180.00 \pm 0.00^{2}$ & $174.53 \pm 3.75^{2}$ & $172.33 \pm 2.02^{a}$ \\
\hline Unripe & $71.90 \pm 0.87^{4}$ & $72.40 \pm 0.87^{4}$ & $70.47 \pm 0.81^{2}$ & $85.80 \pm 4.33^{b}$ & $82.43 \pm 4.56^{b}$ & $100.13 \pm 1.67^{*}$ & $193.10 \pm 5.20^{\mathrm{a}}$ & $189.10 \pm 3.46^{b}$ & $208.53 \pm 0.58^{a, b}$ & $176.70 \pm 0.00^{a, b}$ & $171.40 \pm 1.04$ & $170.37 \pm 5.66^{*}$ \\
\hline Polybag & $70.97 \pm 1.67^{4}$ & $70.93 \pm 0.81^{\text {a,b }}$ & $70.93 \pm 0.81^{2}$ & & $82.83 \pm 4.56^{b}$ & $97.37 \pm 1.44^{\text {a }}$ & & $197.10 \pm 0.00^{b}$ & $205.63 \pm 5.66^{b}$ & & $171.30 \pm 1.91$ & $169.90 \pm 0.00^{a}$ \\
\hline & & & & $88.67 \pm 5.95^{2}$ & & & $194.10 \pm 3.46^{2}$ & & & $172.37 \pm 3.75^{\mathrm{b},}$ & & \\
\hline $\begin{array}{l}\text { Calcuim } \\
\text { carbide }\end{array}$ & $69.50 \pm 3.29^{4}$ & $67.77 \pm 0.10^{b}$ & $65.77 \pm 0.12^{\mathrm{b}}$ & $88.60 \pm 3.29^{2}$ & $91.07 \pm 13.74^{a / p}$ & $99.13 \pm 0.23^{\mathrm{a}}$ & $193.10 \pm 0.00^{a}$ & $200.07 \pm 13.74^{24}$ & $211.33 \pm 1.15^{a}$ & $173.50 \pm 0.00^{b}$ & $173.50 \pm 0.00$ & $171.10 \pm 0.00^{2}$ \\
\hline hotwater & $71.90 \pm 0.86^{2}$ & $71.43 \pm 2.48^{2}$ & $69.50 \pm 3.29^{2}$ & $86.80 \pm 3.81^{4}$ & $100.57 \pm 0.92^{2}$ & $97.20 \pm 0.00^{\mathrm{a}}$ & $192.10 \pm 1.73^{\mathrm{a},}$ & $209.13 \pm 0.06^{a}$ & $208.73 \pm 0.64^{a, b}$ & $166.40 \pm 4.85^{\circ}$ & $172.37 \pm 3.75^{\prime \prime}$ & $173.90 \pm 0.00^{\mathrm{a}}$ \\
\hline
\end{tabular}

Values are mean \pm SD) of triplicate determinations.

Values in the same column having the same superscript letters are not significantly different at the $5 \%$ level. 
Table 2: Haematological indices of Wistar albino rats fed $10 \%$ riped, unripe and artificially riped mango pulp (Mangifera indica) formulated diets

\begin{tabular}{llllll}
\hline Parameters & $\begin{array}{l}\text { Control } \\
\text { (naturally riped) }\end{array}$ & Unripe & Polybag riped & $\begin{array}{l}\text { Calcium } \\
\text { carbide riped }\end{array}$ & $\begin{array}{l}\text { Hot } \\
\text { riped }\end{array}$ \\
\hline $\begin{array}{l}\text { White blood } \\
\text { cell (x10 cell/L) }\end{array}$ & $7.53 \pm 0.06^{\mathrm{c}}$ & $16.27 \pm 0.8^{\mathrm{a}}$ & $10.90 \pm 1.90^{\mathrm{b}}$ & $16.37 \pm 0.06^{\mathrm{a}}$ & $12.43 \pm 0.75^{\mathrm{b}}$ \\
$\begin{array}{l}\text { Lymphocytes } \\
(\%)\end{array}$ & $45.93 \pm 9.12^{\mathrm{a}}$ & $42.57 \pm 1.96^{\mathrm{a}}$ & $39.27 \pm 1.67^{\mathrm{a}}$ & $39.00 \pm 2.94^{\mathrm{a}}$ & $39.10 \pm 1.39^{\mathrm{a}}$ \\
$\begin{array}{l}\text { Neutrophils } \\
(\%)\end{array}$ & $52.17 \pm 0.23^{\mathrm{a}}$ & $48.87 \pm 0.81^{\mathrm{b}}$ & $53.90 \pm 0.69^{\mathrm{a}}$ & $55.07 \pm 4.62^{\mathrm{a}}$ & $53.57 \pm 1.27^{\mathrm{a}}$ \\
$\begin{array}{l}\text { Red blood cell } \\
\left(\mathrm{x} 10^{10} \text { cell/L) }\right.\end{array}$ & $7.14 \pm 0.40^{\mathrm{a}}$ & $6.34 \pm 0.04^{\mathrm{c}}$ & $6.57 \pm 0.22^{\mathrm{b}, \mathrm{c}}$ & $6.35 \pm 0.06^{\mathrm{c}}$ & $6.42 \pm 0.21^{\mathrm{a}, \mathrm{b}}$ \\
$\begin{array}{l}\text { Haemoglobin } \\
\text { (g/dl) }\end{array}$ & $14.43 \pm 0.11^{\mathrm{a}}$ & $12.20 \pm 0.40^{\mathrm{b}}$ & $12.63 \pm 0.06^{\mathrm{b}}$ & $12.23 \pm 0.40^{\mathrm{b}}$ & $12.97 \pm 0.64^{\mathrm{b}}$ \\
$\begin{array}{l}\text { Packed cell } \\
\text { volume (\%) }\end{array}$ & $43.00 \pm 0.69^{\mathrm{a}}$ & $42.03 \pm 0.92^{\mathrm{a}}$ & $42.07 \pm 0.81^{\mathrm{a}}$ & $41.77 \pm 0.46^{\mathrm{a}}$ & $42.80 \pm 0.35^{\mathrm{a}}$ \\
$\begin{array}{l}\text { Platelet count } \\
(\%)\end{array}$ & $874.33 \pm 8.08^{\mathrm{a}}$ & $619.33 \pm 21.94^{\mathrm{b}}$ & $868.67 \pm 165.12^{\mathrm{a}}$ & $622.67 \pm 16.17^{\mathrm{b}}$ & $864.33 \pm 52.54^{\mathrm{a}}$ \\
$\begin{array}{l}\text { Mean platelet } \\
\text { volume (\%) }\end{array}$ & $7.23 \pm 0.29^{\mathrm{a}}$ & $7.63 \pm 0.06^{\mathrm{a}}$ & $7.67 \pm 0.12^{\mathrm{a}}$ & $7.63 \pm 0.06^{\mathrm{a}}$ & $7.57 \pm 0.06^{\mathrm{a}}$ \\
\hline
\end{tabular}

Values are mean \pm SD) of triplicate determinations. Values in the same column having the same superscript letters are not significantly different at the 5\% level.

Table 3:Heamatological indices of Wistar albino rats fed 20\% riped, unrpe and artificially riped mango pulp (Mangifera indica) formulated diets

\begin{tabular}{llllll}
\hline & & \multicolumn{2}{c}{ Mango fuits } & & \\
Parameters & $\begin{array}{l}\text { Control } \\
\text { (naturally riped) }\end{array}$ & Unripe & Polybag riped & $\begin{array}{l}\text { Calcium } \\
\text { carbide riped }\end{array}$ & $\begin{array}{l}\text { Hot water } \\
\text { riped }\end{array}$ \\
\hline $\begin{array}{l}\text { White blood } \\
\text { cell (x10 cell/L) }\end{array}$ & $9.17 \pm 0.58^{\mathrm{c}}$ & $12.30 \pm 0.98^{\mathrm{b}}$ & $11.10 \pm 0.04^{\mathrm{b}}$ & $11.25 \pm 0.58^{\mathrm{b}}$ & $15.40 \pm 3.98^{\mathrm{a}}$ \\
$\begin{array}{l}\text { Lymphocytes } \\
(\%)\end{array}$ & $47.93 \pm 2.83^{\mathrm{b}}$ & $38.23 \pm 13.91^{\mathrm{b}}$ & $47.93 \pm 2.83^{\mathrm{b}}$ & $59.73 \pm 6.35^{\mathrm{a}}$ & $44.67 \pm 4.62^{\mathrm{b}}$ \\
$\begin{array}{l}\text { Neutrophils } \\
(\%)\end{array}$ & $41.13 \pm 2.02^{\mathrm{a}}$ & $44.77 \pm 7.85^{\mathrm{a}}$ & $41.13 \pm 2.02^{\mathrm{a}}$ & $44.10 \pm 2.25^{\mathrm{a}}$ & $46.50 \pm 4.50^{\mathrm{a}}$ \\
$\begin{array}{l}\text { Red blood cell } \\
\left(\mathrm{x} 10^{10} \text { cell/L) }\right.\end{array}$ & $6.43 \pm 0.19^{\mathrm{a}}$ & $6.16 \pm 0.23^{\mathrm{a}}$ & $5.14 \pm 0.33^{\mathrm{b}}$ & $3.66 \pm 0.39^{\mathrm{c}}$ & $6.41 \pm 0.09^{\mathrm{a}}$ \\
$\begin{array}{l}\text { Haemoglobin } \\
(\mathrm{g} / \mathrm{dl})\end{array}$ & $13.47 \pm 0.12^{\mathrm{a}}$ & $11.03 \pm 1.44^{\mathrm{b}}$ & $12.47 \pm 0.12^{\mathrm{a}}$ & $10.00 \pm 0.17^{\mathrm{c}}$ & $12.23 \pm 0.98^{\mathrm{a}}$ \\
$\begin{array}{l}\text { Packed cell volume } \\
(\%)\end{array}$ & $39.00 \pm 0.52^{\mathrm{a}}$ & $38.43 \pm 0.92^{\mathrm{a}}$ & $39.00 \pm 0.52^{\mathrm{a}}$ & $39.40 \pm 1.04^{\mathrm{a}}$ & $38.90 \pm 2.77^{\mathrm{a}}$ \\
$\begin{array}{l}\text { Platelet count } \\
(\%)\end{array}$ & $865.00 \pm 15.59^{\mathrm{a}}$ & $845.33 \pm 33.49^{\mathrm{a}}$ & $860.00 \pm 15.59^{\mathrm{a}}$ & $714.00 \pm 36.37^{\mathrm{b}}$ & $733.67 \pm 16.74^{\mathrm{b}}$ \\
$\begin{array}{l}\text { Mean platelet } \\
\text { volume (\%) }\end{array}$ & $6.83 \pm 0.06^{\mathrm{a}}$ & $6.98 \pm 0.06^{\mathrm{a}}$ & $6.93 \pm 0.06^{\mathrm{a}}$ & $7.33 \pm 0.46^{\mathrm{a}}$ & $7.03 \pm 0.12^{\mathrm{a}}$ \\
\hline
\end{tabular}

Values are mean $\pm \mathrm{SD}$ ) of triplicate determinations. Values in the same column having the same superscript letters are not significantly different at the $5 \%$ level. 
Table 4: Haematological indices of Wistar albino rats fed 30\% riped, unriped and artificially riped mango pulp (Mangifera indica) formulated diets

\begin{tabular}{llllll}
\hline \multicolumn{5}{c}{ Mango fruits } \\
\hline Parameters & $\begin{array}{l}\text { Control } \\
\text { (naturally } \\
\text { riped) }\end{array}$ & Unripe & Polybag riped & $\begin{array}{l}\text { Calcium } \\
\text { carbide riped }\end{array}$ & $\begin{array}{l}\text { Hot water } \\
\text { riped }\end{array}$ \\
\hline $\begin{array}{l}\text { White blood } \\
\text { cell (x10 cell/L) }\end{array}$ & $9.17 \pm 0.98^{\mathrm{b}}$ & $11.93 \pm 0.58^{\mathrm{a}}$ & $10.80 \pm 0.00^{\mathrm{a}}$ & $7.23 \pm 0.63^{\mathrm{c}}$ & $12.00 \pm 1.73^{\mathrm{a}}$ \\
$\begin{array}{l}\text { Lymphocytes } \\
(\%)\end{array}$ & $54.47 \pm 3.58^{\mathrm{a}}$ & $60.07 \pm 8.02^{\mathrm{a}}$ & $51.77 \pm 1.09^{\mathrm{a}}$ & $59.07 \pm 9.75^{\mathrm{a}}$ & $53.40 \pm 1.73^{\mathrm{a}}$ \\
$\begin{array}{l}\text { Neutrophils } \\
(\%)\end{array}$ & $42.70 \pm 10.22^{\mathrm{a}}$ & $34.53 \pm 4.39^{\mathrm{a}}$ & $46.13 \pm 4.27^{\mathrm{a}}$ & $37.10 \pm 8.83^{\mathrm{a}}$ & $43.53 \pm 8.78^{\mathrm{a}}$ \\
$\begin{array}{l}\text { Red blood cell } \\
\left(\mathrm{x} 10^{10} \text { cell/L) }\right.\end{array}$ & $6.69 \pm 0.07^{\mathrm{a}}$ & $6.34 \pm 0.15^{\mathrm{a}}$ & $6.12 \pm 0.31^{\mathrm{a}}$ & $6.23 \pm 0.12^{\mathrm{a}}$ & $6.56 \pm 0.45^{\mathrm{a}}$ \\
$\begin{array}{l}\text { Haemoglobin } \\
\text { (g/dl) }\end{array}$ & $14.97 \pm 0.17^{\mathrm{a}}$ & $12.33 \pm 0.13^{\mathrm{b}}$ & $12.30 \pm 0.87^{\mathrm{b}}$ & $11.21 \pm 1.56^{\mathrm{b}}$ & $12.37 \pm 0.98^{\mathrm{b}}$ \\
$\begin{array}{l}\text { Packed cell volume } \\
(\%)\end{array}$ & $38.37 \pm 1.32^{\mathrm{a}}$ & $40.73 \pm 2.31^{\mathrm{a}}$ & $37.93 \pm 0.58^{\mathrm{a}}$ & $38.40 \pm 1.73^{\mathrm{a}}$ & $39.27 \pm 2.89^{\mathrm{a}}$ \\
$\begin{array}{l}\text { Platelet count } \\
(\%)\end{array}$ & $909.67 \pm 45.61^{\mathrm{a}}$ & $701.00 \pm 55.43^{\mathrm{b}}$ & $715.00 \pm 31.18^{\mathrm{b}}$ & $773.33 \pm 108.54^{\mathrm{b}}$ & $730.00 \pm 5.20^{\mathrm{b}}$ \\
$\begin{array}{l}\text { Mean platelet } \\
\text { volume (\%) }\end{array}$ & $6.97 \pm 0.23^{\mathrm{a}}$ & $7.17 \pm 0.06^{\mathrm{a}}$ & $7.03 \pm 0.12^{\mathrm{a}}$ & $77.20 \pm 0.00^{\mathrm{a}}$ & $7.03 \pm 0.12^{\mathrm{a}}$ \\
\hline
\end{tabular}

Values are mean $\pm \mathrm{SD}$ ) of triplicate determinations. Values in the same column having the same superscript letters are not significantly different at the 5\% level.

\section{Discussion}

At $10 \%$ level of incorporation, there was no significant difference $(\mathrm{P}<0.05)$ in the level of high density lipoprotein (HDL) in all the groups, but at $20 \%$ and $30 \%$ levels the groups of rats fed calcium carbide riped mango pulp diets were significantly lower in HDL $(67.77 \pm 0.10$ at $10 \%$ and $65.77 \pm 0.12$ at $20 \%$ ) compared to test groups and control. $(72.3 \pm 13.74$ at $10 \%$ and $70.47 \pm 0.81$ at $20 \%$ ). High density lipoprotein is often referred to as the "good" cholesterol attributed to its ability to remove cholesterol fromthe walls of the arteries and transports it to the liver thereby unclogging the walls of the arteries and consequently, lowering the risk of heart attack. Secondly, it helps prevent oxidation of low density lipoprotein and it is thought to have antioxidant properties (Brunzell et al., 2008). More so, Wierzbicki, (2005) submitted the existence of an inverse relationship between high density lipoprotein level and the risk of cardiovascular diseases. This means that the decreased HDL observed in this study may not be beneficial to the animals since cardiovascular risk is increased (Adebayo et al., 2015).Finding disagrees with Gbakon et al., (2018) who had reported an increase in HDL concentration in a similar work. Variation may be attributed to specie difference, ripening methods employed or stage of maturity of fruits used (Iroka et al., 2016). 
The study revealed a statistically significant increase in the concentrations of low density lipoprotein (LDL) in the rats fed $10 \%$ artificially ripened mango formulated diet. The elevated amount of LDL and a concomitant decrease in HDL could be attributed to two factors; (1) a possible increase in the amount of acetyl CoA, (a key substrate in cholesterol biosynthesis) resulting probably from increased beta oxidation of free fatty acids (Adebayo et al., 2005), (2) may be occasioned by an inhibition of the enzyme Lipoprotein lipase which metabolizes free fatty acid. The inhibition maybe a response to the presence of food contaminants such as arsenic and lead found in the chemical materials used in the induced ripening process which may have leaked into the fruit in the course of ripening(Sogo-Temi et al., 2014;Afolabi et al.,2015).

The increase in total cholesterol observed in the rats fed all three levels of formulated diets may predispose animals to arthrosclerosis and other related diseases (Treasure et al., 1995). Increase may be attributed to decrease in the metabolism of acetyl CoA arising probably from reduced beta oxidation of fatty acid (Rang et al., 1995) Furthermore the significantly decreased concentration of triglycerides in the rats fed $10 \%$ artificially riped mango diet as observed in this study could be attributed to reduced lipolysis (Afolayan et al., 2009).

Changes in the lipid profile of animals such as cholesterol, high and low-density lipoprotein cholesterols, and triglycerides may be employed in obtaining beneficial information on lipid metabolism and would give an insight to the cardiovascular health status of the animals (Yakubu et al., 2008) The observed decrease in HDL and a concomitant increase in LDL and serum cholesterol is indicative of Hyperlipemia. A disease characterized by the increased amount of cholesterol, triglycerides, low density lipoprotein and decreased levels of high density lipoprotein cholesterol. It is a risk factor of cardiovascular diseases; which is a leading cause of morbidity and mortality all over the world (Yusuf et al., 2001). It has been established that reduction of total cholesterol or Low Density Lipoprotein cholesterol (LDL-c) is associated with decreased risk of atherosclerosis and coronary heart disease (Grundy et al., 2004) suggesting that artificial ripening of mango with chemicals such as calcium carbide, may increase lipid profile and consequently may increase the incidence of cardiovascular diseases such as Arteriosclerosis and Hypertension (Treasure et al.,1995; Shepherd, 1998; Enas 1999;Lichtennstein et al., 2006b). This may aggravate erectile dysfunction (Fielman et al., 1994) thus lending support to previous report that artificially ripened fruits may have numerous health hazards including reproductive disorders (Hossain et al., 2015).

Investigations of haematological factors cannot only be used to ascertain the level of disastrous impact of a plant product on the blood of an 
animal, but it can also be utilized to describe blood related roles of the plantproducts (Yakubuet al., 2007). Investigations of blood factor is crucial in risk analysis as variations in the haematological system have more informative value for human toxicity when the data is analysed from animal investigations (Olson et al., 2000, Celik \& Suzek, 2008). Thus the level of blood components is characteristic of one's health status.

The result of haematological investigation revealed that the total White blood cell (WBC) was significantly elevated in the group of rats fed $10 \%$ unripe mango and calcium carbide induced ripe mango formulated diets. This finding correlates with previous by Igbinaduwa and Aikpitanyi, (2016) who submitted a significant increase in WBC of Wistar rats fed various fruit treated with calcium carbide. Similarly, Hong et al., (1989) had reported similar leukocytosic response in mice arsine gas poisoning. Studies conducted by Dhembare, (2014) on haematological changes in European rabbit, Oryctolaguscunisculus subjected to "ethereal" (a ripening agent) also submitted a similar observation. The White blood cells respond to various stresses including infection and irritants, thus altered number of WBC is a normal reaction on exposure to toxicants (Kori-siakpere, 2007). The observed increase in WBC count may be attributed to two factors; (1) an immune response of the rats to zenobiotics; (2)possibly high levels of vitamins and phytochemicals (tannins and saponins) present in the fruits which must have enhanced the boost in immunity (Chung et al., 1998;Soetan,008;European food and safety Authority, 2009) hence it was reflected in the WBC by a subsequent rise. Interestingly, the reverse was observed in the rats fed $30 \%$ calcium carbide induced ripe mango formulated diet as the total WBC for this group was significantly lower compared with the control. The decrease in WBC may be due to impairment in the rate of synthesis and mobilization of WBC suggesting that the rats in this group may have impaired ability to combat infection which may not be unconnected to arsenic toxicity (Dhembare 2013; Afolayan et al., 2015). The significantly elevated level of neutrophils as observed in the group of rats fed $10 \%$ calcium carbide riped formulated diet, may initiate phagocytosic responses in the animals while the observed elevation in lymphocytes suggests that the effector cells were not yet adversely affected by the alterations in the activities of immune system as reported by Adebayo et al., (2005).

Reduction in red blood cell count as observed in the rats fed $10 \%$ and $20 \%$ artificially riped mango suggests erythropenia- a condition marked with significant reduction of haemoglobin content owing to haemopoiesis. Erythropenia results in aneamia which could be attributed to inhibition of the enzyme, erythropoietin or due to alterations in the process of haemoglobin synthesis (Sogo-Temiet al., 2014) or may be attributed to increased rate of heamolysis arising from increased phagocytosis. 
Furthermore,the significant decrease in Platelet count as observed in all the group of rats fed the artificially riped mango formulated diet when compared with the control is indicative of reduced thrombopoietin as reported by $\mathrm{Li}$, et al., (1999). Platelets are vital in the clotting of blood vessels suggesting that rats in this group may have impaired ability in the blood coagulation process (Taniguchi et al., 2003; Kaushansky, 2009).

\section{Conclusion}

Findings have shown that artificial ripening of fruits especially by chemicals such as calcium carbide reduced high density lipoprotein and increased low density lipoprotein and cholesterol and also caused alterations in the haematological indices. Sequel to this, there is then the requirement for institutional and legislative supports as well as policies to stop the utilization of harmful chemical compounds such as calcium carbide in the ripening of mangoes and other fruits.

\section{References:}

1. Adams, T.B. \& Colner, W. (2008). The Association of multiple risk factors with fruits and vegetable intake among a nationwide sample of college students. Journal of American College Health; 56(4):45561.

2. Adebayo, J. O., Adesokan, A. A., Olatunji, L. A., Buoro, D. O. \& Soladoye, A. O. (2005). Effect of ethanolic extract of Bougainvillea spectabilisleaveson haematological and serum lipid variables in rats. Biochemistry; 17: 2145-50

3. Afolabi, K.A., Wusu, A.D., Ogunrinola, O. O., Abam, E.O \& Babayemi, D O. (2015) Arsenic-induced dyslipideamia in male albino rats comparison between trivalent and pentavalent inorganic arsenic in drinking water. BMC Pharmacology and Toxicology; 16:15-21.

4. Afolayan, J. M.., Yakubu, T., Appidi, J. R \& Mostafa, M. (2009). Toxicological implications of aqueous extract of Clematis brachiataThunb. leaves in male Wistar rats African Journal of Pharmacy and Pharmacology; 3(11):531-38.

5. Akbaraly, T. N., Sabia, S., Shipley, M. J., Batty, G. D. \& Kivimaki, M. (2013). Adherence to healthy dietary guidelines and future depressive symptoms: evidence for sex differentials in the Whitehall II study. The American Journal of Clinical Nutrition; 97(2): 419-27.

6. Allgo, W. A., Wardle, J. \& Steptoe, A. (2001) Depressive symptoms, social support, and personal health behaviors in young men and women. Health Psychology; 20(3):223-24.

7. Amarakoon, R., Illeperuma, D. C. K. \& Sarananda, K. H. (1999). Effect of calcium carbide treatment on ripening and quality of 
Velleicolomban and Willard mangoes. Tropical Agricultural Research;11: 54-60.

8. Banadda, N; Namawejje, H; Ayaa, F; Kigozi, J.B \& Sendagi, S (2011). Diffusive flux modeling of lead migration from black polythene bags into food: A case study of green bananas (Matooke). African journal of Food science; 5(5):313-19.

9. Bruzell, J.D., Davidson, M., Furberg, C.D.,Goldberg, R.B., Howard, B.V., Stein, J.H., et al (2008) Lipoprotein management in patients with cardio metabolic risk. Diabetes care; 31 (4):811-22

10. Boffetta, P., Couto, E., Wichmann, J., Ferrari, P., Trichopoulos, D.\&, Bueno-de-Mesquita, H.B. (2010) Fruit and vegetable intake and overall cancer risk in the European Prospective Investigation into Cancer and Nutrition (EPIC).Journal of the National Cancer Institute; 102(8):529-37.

11. Celik I, \& Suzek H (2008).The hematological effects of methyl parathion in rats. Journal of harzardous material;153:1117-21

12. Dhembare J. Gholap, A. B Reena Khatode, (2011a).Journal Exp. Zoo. India; 14 (2): 523-26.

13. Dhembare, A. J. (2013). Bitter truth about fruit with reference to artificial ripener. $\quad$ Archives of Applied Science Research; 5 (5): 45-54.

14. Enas, E. A., (1999).Cholesterol made easy. The good, bad and the ugly cardioresearch, USA.pp1-3.

15. European Food and Safety Authority (2009). Scientific Opinion of the Panel on Contaminants in the Food Chain on a request from the European Commission on Saponins in Madhucalongifolia L. an undesirable substances in animal feed. The European Food \& Safety Authority (ESFA) journal, 979:1-36

16. Farina, V., Mazzaglia, A., Padoan, D., \& Barone, F. (2013a) Chemical-physical and sensory characterization of mango fruits (Mangifera indica L.) cultivated in Sicily (Italian). Acta Italus Hortus; 12:110-13.

17. Fielman A., Goldstein D. G., Hatzichriston, R. J., Krane \&J. B. Mckinlay, (1994).Impotence and its medical and psychological correlates.Results of the Massachusets male aging. study Journal; 151:54-61.

18. Gbakon S. A., Ubwa T. S., Ahile U. J., Obochi O., Nnannadi I., Yusufu, A \& Ikagu, M. (2018). Studies on Changes in Some Haematological and Plasma Biochemical Parameters in Wistar Rats Fed on Diets Containing Calcium Carbide Ripened Mango Fruits. International Journal of Food Science and Nutrition Engineering; 8(2): $27-36$. 
19. Goldmann I. L., Kader A. A. \& Heintz C. (1999). Influence of production, handling, and storage on phytonutrient content of Foods.Nutritional Review;57:46:52.

20. Grundy, S. M., Cleeman, J. I. \& C. N. Merz, (2004). Implications of recent clinical trials for the national cholesterol education program adult panel on detection, evaluation and treatment of high blood cholesterol in adults. Journal of American Medical Association; 285:2486-97.

21. Halsted, J. A. and Halsted, C. H. (1991). The laboratory in clinical medicine: Interpretation and application, @ ndedition.WB. Saunders Company, Philadelphia.pp.281-283.

22. Harborne J. B. (1993). Phytochemical methods. Chapman and Hall Ltd, London; 279.

23. Hayes, D. P. (2005). Protective role of fruits and vegetables against radiation induced cancer. Nutritional Review. 63(9):303-311.

24. Hong, H., B. Fowler, \& G. Boorman.(1989). Hematopoietic effects in mice exposed to arsine gas.Toxicology and applied pharmacology; 97(1):173-82.

25. Hossain, M. F., Akhtar, S. and Anwar, M. (2015). Health hazarads posed by the consumption of artificially ripened fruits in Bangladesh. International Food Research Journal, 22(5),1755-1760.

26. Igbinaduwa P.,\& Aikpitanyi-Iduitua R. (2016). Calcium carbide induced alterations of some haematological and serum biochemical parameters of wistar rats. Asian Journal of Pharmaceutical and Health Sciences. 6(1):1360-70.

27. Iroka, C. F., Akachukwu, E. E., Adimonyemma, R. N., Nkumah, C. O \& Nwogiji C.O. (2016). Effects of Induced Ripening on the Proximate, BiochemicalandMineral Compositions of Carica papaya (Pawpaw Fruit) European Journal of Medicinal Plants, 15(3):1-10.

28. Jacka, F.N., Kremer, P.J.,Leslie, E .R., Berk, M., Patton, G.C \& Toumbourou, J.W.(2010) Associations between diet quality and depressed mood in adolescents: results from the Australian Healthy Neighbourhoods Study.Australian and New ZealandJournal of Psychiatry; 44(5):435-42.

29. Kader, A. A. (2007) Post harvest Techno. Hort. Crops.Univ. of California, 2002, 157.

30. Kaunshanky, K. (2009). Determinants of platelet number and regulation of thrombopoiesis. Haematology; 1:147-52.

31. Kjuus, H, A.,Andersen, S. and Langard. (2007). Incidence of cancer among workers producing calciumcarbide.Porsgrunn and the Cancer Registry of Norway. 2 Montebello, Oslo 3, Norway. 
32. Kori - Siakpere, O., Adamu, K. M. \& Madukelum I. T. (2007). Hematological effect of sublethal of paraquat on the African catfish, Clarias gariepinus ( steichthyes: Claridae). Research Journal of Environmental Science, 1:331-35

33. Li, J., Xia, Y. \& Kuter, D.J. (1999). Interaction of thrombopoietin with the platelet complements receptor in plasma: binding, internalization, stability and pharmacokinetics. British Journal of Haematology; 106: 345-56.

34. Lichtenstein, A.H., Appel. L.J., Brands, M., Carnethon,M., Daniels, S., Franklin. B., etal (2006b) Diet and lifestyle recommendations revision. A scientific statement from the American Heart Association.Nutrition Committee Circulation; 114(1): 82-96.

35. Mauseth, J.D (2003). Botany: An introduction to plant Biology. $\left(3^{\text {rd }}\right.$ ed).

36. Olson, H., Betton, G., Robinson, D., Thomas, K., Monro, A., Kolaja, G.,et al. (2000). Concordance of toxicity of pharmaceuticals in humans and in animals.Regulatory, Toxicology and Pharmacology; 32:56-67.

37. Onyeani, C. A., Osunlaja, O.S., Sosanya O.S \& Oworu, O.O (2012). Mango fruit anthracnose and the effects on mango yield and market values in Southwestern Nigeria. AsianJournal of Agricultural Research; 6:171-79.

38. Oyebode O, Gordon-Dseagu V, Walker A,\& Mindell J.S (2014). Fruit and vegetable consumption and all-cause cancer and CVD mortality: analysis of Health Survey for England data. Journal of Epidemiology and Community Health, 68(9):856-62.

39. Rang, H. P., Dale, M. M. \& Ritter, J. M. (1995).Pharmacology. (3rd ed) Churchill Livingstone, New York.

40. Rossato, S. B., Haas, C., Raseira, M.C., Moreira, J.C \& Zuanazzi, J. A. (2009).Antioxidant potentialof peels and fleshes of peaches from different cultivars. "Journal of Medicinal. Food ; 12(5):1119-26.

41. Ruchitha, G. (2008). Effects of diluted ethylene glycol as a fruitripening agent.GlobalJournal Biotechnology and Biochemistry; 3:813

42. Shepherd, J. (1998). Identifying patients at risk of coronary heart disease: treatment implications. European Heart Journal; 19:1776-83.

43. Soetan, K.O (2008).Pharmacological and otherbeneficial effects of anti-nutritional factors in plants- A review. African journal of Biotechnology, 7:4713-21

44. Sogo-Temi, C. M., Idowu, O. A \& Idowu, E. (2014) Effect of biological and chemical ripening agents on the nutritional and metal 
composition of banana (Musa spp). Journal of Applied Science and Environmental Management; 18 (2):243-46.

45. Taniguchi, A., Fukushima, M., Seino, Y., Sakai, M., Yoshi, S., Nagasaka, S.,etal,(2003). Platelet count is independently associated with insulin resistance in non obese Japanese type 2 diabetic patients. Metabolism; 52(10):1246-49

46. Treasure, C. B., Klein, J. L., Weintraub, W. S., Talley, J. D., Stillabow, M. E., Kisonski, etal,(1995). Beneficial effects of cholesterol lowering therapy on thecoronary endothelium in patients with coronary heart disease.TheNew England Journalof medicine;332: 481-87.

47. Wierzbicki, A. S., (2005). Have we forgotten the pivotal role of the high density lipoprotein cholesterol in atherosclerosis prevention? Current. Medical. Research Opinion:21:299-06.

48. Yakubu, M. T., Akanji, M. A. \& Oladiji, A. T. (2007).Haematologicalevaluation in male albino rats following chronic administration of aqueous extract of Fadogiaagrestisstem. Pharmacognosis Magazine, 3, 34.

49. Yakubu, M.T., Akanji, M.A. \& Oladiji, A.T. (2008). Alterations in serum lipid profile of male rats by oral administration of aqueous extract of Fadogia argrestis stem. Research Journal of Medicinal Plant: 2: 66-73.

50. Yusuf, S. S., Reddy, S. Ounpuu, S. \& S. Anand, (2001). Global burden of cardiovascular disease Part I: General consideration, the epidemiologic transition, risk factor and impact of urbanization. Circulation, 104, 2746-53. 